Dermatoglyphics: An International Bibliography 


\section{World Anthropology}

General Editor

SOL TAX

\section{Patrons}

CLAUDE LÉVI-STRAUSS

MARGARET MEAD

LAILA SHUKRY EL HAMAMSY

M. N. SRINIVAS

MOUTON PUBLISHERS - THE HAgUE - PARIS DISTRIBUTED IN THE USA AND CANADA BY ALDINE, CHICAGO 


\section{Dermatoglyphics}

An International Bibliography

By

JAMSHED MAVALWALA

MOUTON PUBLISHERS - THE HAgUE • PARIS DISTRIBUTED IN THE USA AND CANADA BY ALDINE, CHICAgO 
Copyright (C) 1977 by Mouton Publishers. All rights reserved.

No part of this publication may be reproduced stored in a retrieval system, or transmitted in any form or by any means, electronic, mechanical, photocopying, recording or otherwise without the written permission of Mouton Publishers, The Hague

Distributed in the United States of America and Canada by Aldine Publishing Company, Chicago, Illinois ISBN 9027979995 (Mouton) 0202900517 (Aldine) Jacket photo by A. G. de Wilde Cover and jacket design by Jurriaan Schrofer Printed in Great Britain 
for Patricia

witbout whom this book would never bave come to pass and

for Darius and Cyrus descendants of emperors in spite of whom this work was completed. 
